УДК 616.24-002.155

$\mathrm{DOI}$

(C) К. Ю. КРЕНЬОВ, Н. М. НЕБЕЛЮК

Хмельницька обласна лікарня

\title{
Інтенсивна терапія тяжких пневмоній у відді.ленні анестезіології та інтенсивної терапії з використанням сучасних стратегій респіраторної терапіï
}

\author{
K. YU. KRENIOV, N. M. NEBELYUK
}

Khmelnytsk Regional Hospital

\section{INTENSIVE ACUTE PNEUMONIES TREATMENT IN THE DEPARTMENT OF ANAESTESIOLOGY AND INTENSIVE THERAPY USING MODERN RESPIRATORY THERAPY STRATEGIES}

Пневмонії є однією із вагомих причин госпіталізації та смертності пацієнтів у ВАІT. У структурі загальних причин смертності тяжкі позагоспітальні пневмонії (ПП) складають 8,6-9,5 \% [7]. Особливої увагипотребуєїх розвиток у хворихізрізноманітними імунодефіцитними станами [3, 8]. На даний час актуальним $є$ затяжний та ускладнений перебіг гострих пневмоній, що розвинулись на тлі “нових інфекцій”, зокрема грипу H1N1 [1, 2]. Для стратифікації ризику та оптимізації лікування у таких пацієнтів існують сучасні рекомендації, зокрема $[1,3,8]$. Критерії тяжкого перебігу ПП (Рекомендації Російського респіраторного товариства, 2010):

- Клінічні

ГДН - частота дихання більше 30 за хвилину, насичення крові киснем менше 90 \%
Гіпотензія - САТ менше 90 мм рт. ст., ДАТ менше 60 мм рт. ст.

Дво- або багаточасткове ураження

Порушення свідомості

Позалегеневе джерело інфекції (менінгіт, абсцес головного мозку та ін.)

- Лабораторні

Лейкопенія менше $4 \times 10^{9}$ /л

Гіпоксемія $\left(\mathrm{PaO}_{2}\right.$ менше 60 мм рт. ст. або $\mathrm{SaO}_{2}$ $<90 \%)$

Гемоглобін $<100$ г/л, гематокрит $<30$ \%

ГНН (анурія, креатинін крові більше 176 мкмоль/л, сечовина 20 ммоль/л і більше).

ПП розцінюється як тяжка при наявності хоча б одного критерію. Згідно з наказом МОЗ України, 2007: хворі з тяжким перебігом потребують прове-

PSI - Pneumonia Severity Index (дослідження PORT)

\begin{tabular}{|c|c|}
\hline Характеристика пацієнтів & Кількість балів \\
\hline \multicolumn{2}{|c|}{ Демографічні дані } \\
\hline BiK & Вік (у роках) \\
\hline \multicolumn{2}{|c|}{ Дані фізикального обстеження } \\
\hline Порушення свідомості & +20 \\
\hline ЧСС $\geq 125$ за хв & +10 \\
\hline Частота дихання $\geq 30$ за 1 хв & +20 \\
\hline Систолічний АТ < 90 мм рт. ст. & +20 \\
\hline Температура $<35^{\circ} \mathrm{C}$ або $\geq 40^{\circ} \mathrm{C}$ & +15 \\
\hline \multicolumn{2}{|c|}{ Лабораторні дані } \\
\hline Гематокрит < $30 \%$ & +30 \\
\hline $\mathrm{pH}<7,35$ & +30 \\
\hline Сечовина в сироватці крові > 10,7 ммоль/л & +20 \\
\hline Натрій у сироватці < 130 ммоль/л & +20 \\
\hline Глюкоза в сироватці > 13,9 ммоль/л & +10 \\
\hline $\mathrm{pO}_{2}<60$ мм рт. ст. або $\mathrm{SaO}_{2}<90 \%$ & +10 \\
\hline Плевральний випіт & +10 \\
\hline
\end{tabular}


дення інтенсивної терапії (смертність сягає 50 \%). Основними збудниками $\epsilon$ : Streptococcus pneumoniae, Legionella pneumoniae, грамнегативні анаероби, Mycoplasma pneumoniae, респіраторні віруси, Наеmophilus influenzae, гриби, Pseudomonas aureginosa.

У великої кількості хворих на тяжкі пневмонії їх перебіг закономірно ускладнюється розвитком респіраторного дистрес-синдрому, що потребує респіраторної підтримки $[1,3,8]$. Існування на сучасному етапі методики неінвазивної ШВЛ відкрило нову сторінку в лікуванні таких пацієнтів [4, $5,6]$.

Метою роботи було дослідження випадків тяжких пневмоній у хворих із супутніми імунодефіцитними станами та можливості сучасних респіраторних стратегій у їх лікуванні.

Клінічний випадок 1. Хвора Ш., 1946 р. н., перебувала на стаціонарному лікуванні у ВАІТ ХОЛ з 23.09.13 до 10.10.13 з діагнозом гострої двобічної позагоспітальної полісегментарної пневмонії III. Хронічний вірусний гепатит С. IXC. Дифузний кардіосклероз. Персистуюча форма фібриляції передсердь. СН - I-II А. ФК - II ст. Гіпертонічна хвороба II ст. 3 анамнезу відомо, що захворіла після ГРВI, протягом тижня турбували непродуктивний кашель, гіпертермія до 39 $\mathrm{C}$, задишка, що прогресувала в динаміці. В зв' язку із неефективністю консервативної терапії на амбулаторному етапі госпіталізована в ВАІТ ЦРЛ, де протягом доби відзначено погіршення стану; переведена в ХОЛ на 8-му добу захворювання. При госпіталізації стан тяжкий, задишка до 40/хв, гіпотензія - 90/60 мм рт. ст., ЧСС - 120-132/хв, серцева діяльність аритмічна; аускультативно в нижніх відділах легень (справа до кута лопатки) дрібноміхурчасті та крепітувальні вологі хрипи. $\mathrm{SpO}_{2}-60 \%\left(-\mathrm{O}_{2}\right)$ та $66 \%\left(+\mathrm{O}_{2}\right)$. Рентгенологічно на рентгенограмі з ЦРЛ (рис. 1).

Проведено контрольну рентгенографію (рис. 2).

Призначено терапію: сульцеф - 2000 мг двічі на добу, максицин - 500 мг один раз на добу, лазолван, кисневу терапію лицевою маскою із потоком кисню 8 л/хв. Показники сатурації протягом доби продовжували знижуватись - $42 \%\left(-\mathrm{O}_{2}\right)$, відзначено негативну рентгенологічну динаміку. Стан хворої розцінено як тяжку пневмонію на фоні вторинного імунодефіциту (хронічний гепатит С) із розвитком ГРДС синдрому (рис. 3). В лабораторних обстеженнях: лейкоцитоз 15 Г/л, паличкоядерні нейтрофіли -7 \%, гематокрит - 0,34 л/л, тромбоцити - 248 Г/л, наявні показники ниркової дисфункції: сечовина 26,3 ммоль/л, креатинін - 0,08 ммоль/л. Звертала на себе увагу відсутність температурної реакції, малопродуктивний кашель із виділенням геморагічного харкотиння. Критерії ГРДС/ГПЛ [8, 9]: гострий

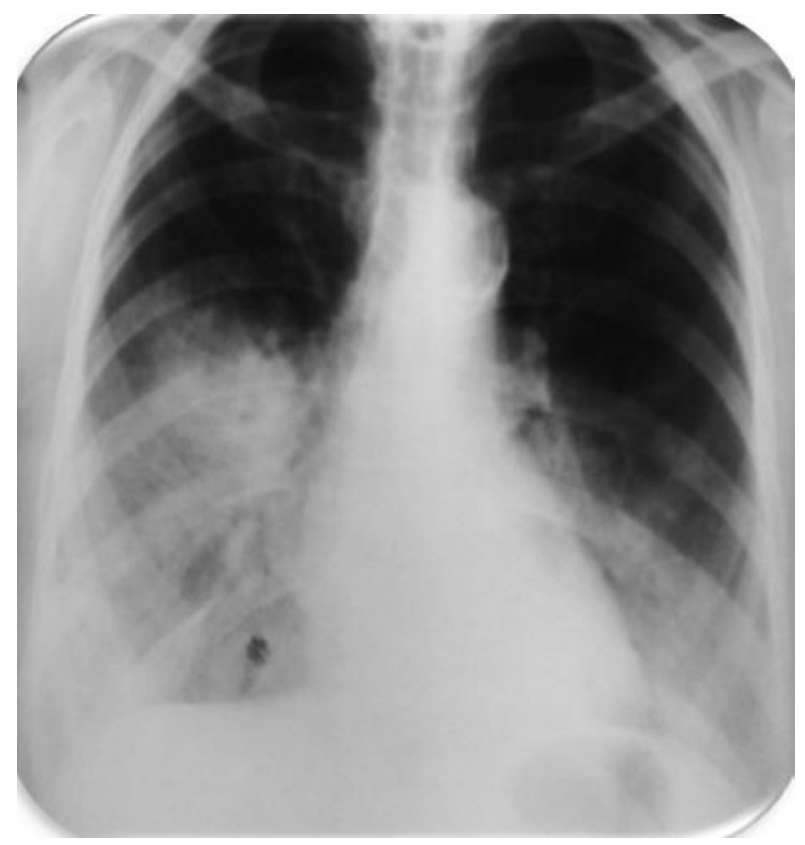

Рис. 1

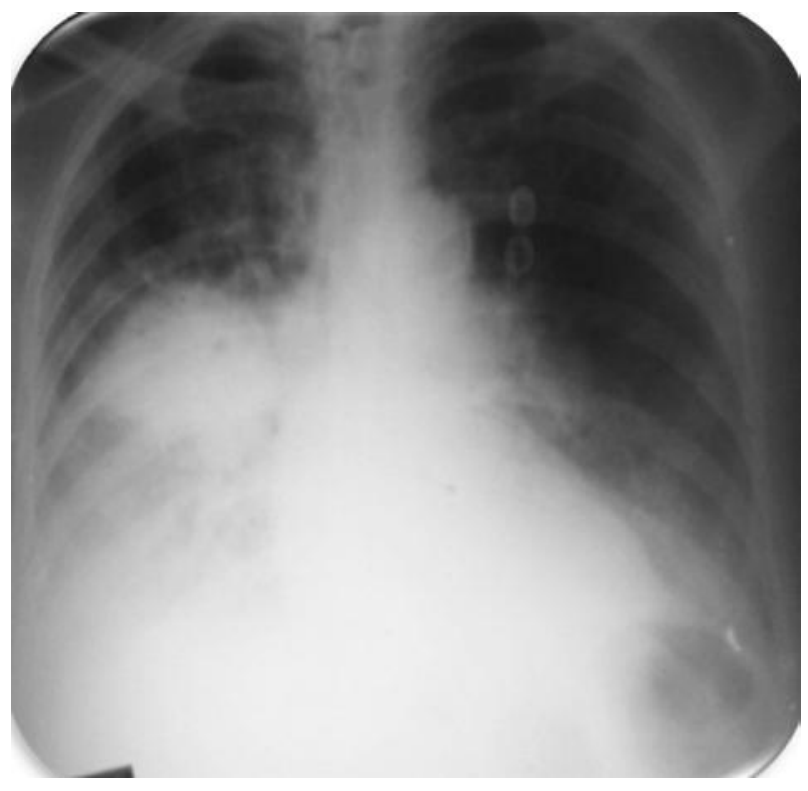

Рис. 2

початок; наявність передумовлюючого стану; двобічні інфільтрати на фронтальній рентгенограмі; $\mathrm{PaO}_{2} / \mathrm{FiO}_{2}$ менше 200 мм рт. ст. при ГРДС та 300 при ГПЛ; ТЗЛК менше або дорівнює 18 мм рт. ст. або відсутність ознак лівопередсердної гіпертензії (дана рекомендація потребує перегляду); єдиний критерій - бронхоальвеолярний лаваж (нейтрофіли, білок). Протягом трьох діб стан хворої з негативною динамікою, утримується гіпоксемія, незважаючи на високі концентрації кисню, мали місце порушення свідомості (в'ялість, байдужість, гіподинамія), додаткова мускулатура виражено брала участь в акті дихання, але дихання лишалось поверхневим. 


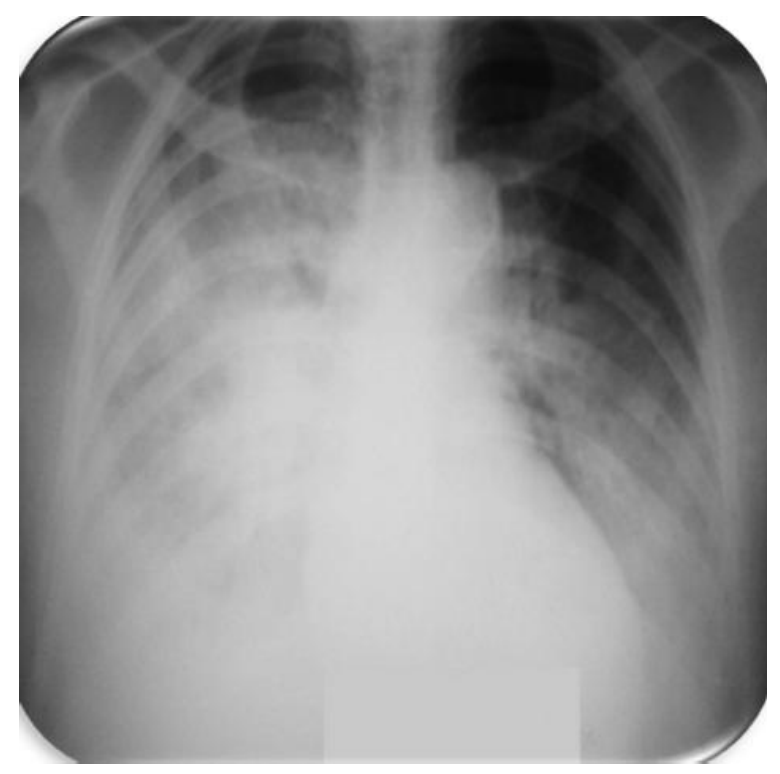

Рис. 3

У зв'язку із неефективністю маскової кисневої терапії хвору вирішено перевести на неінвазивну ШВЛ (3-тя доба): апарат “Carina” в режимі BiPAP із параметрами: ЧД - 32/хв, Pins - 20 см вод. ст., РЕЕР - 8 см вод. ст., $\mathrm{FiO}_{2}-60 \%$. Хвора легко адаптувалась до ШВЛ; режим антибактеріальної терапії не змінювали (рис. 4).

Рентгенограма через 6 год неінвазивної ШВЛ (рис. 5).

На наступну добу проведено контрольну рентгенографію (рис. 6).

Хвора перебувала на ШВЛ 5 діб, на 3-тю добу на фоні адаптації до апаратного дихання прояви енцефалопатії (гіпокапнія), що потребувало зміни режиму НІШВЛ: ЧД- 26/хв, $\mathrm{PEEP}-+6+8 \mathrm{~cm} \mathrm{H}_{2} \mathrm{O}, \mathrm{FiO}_{2}$

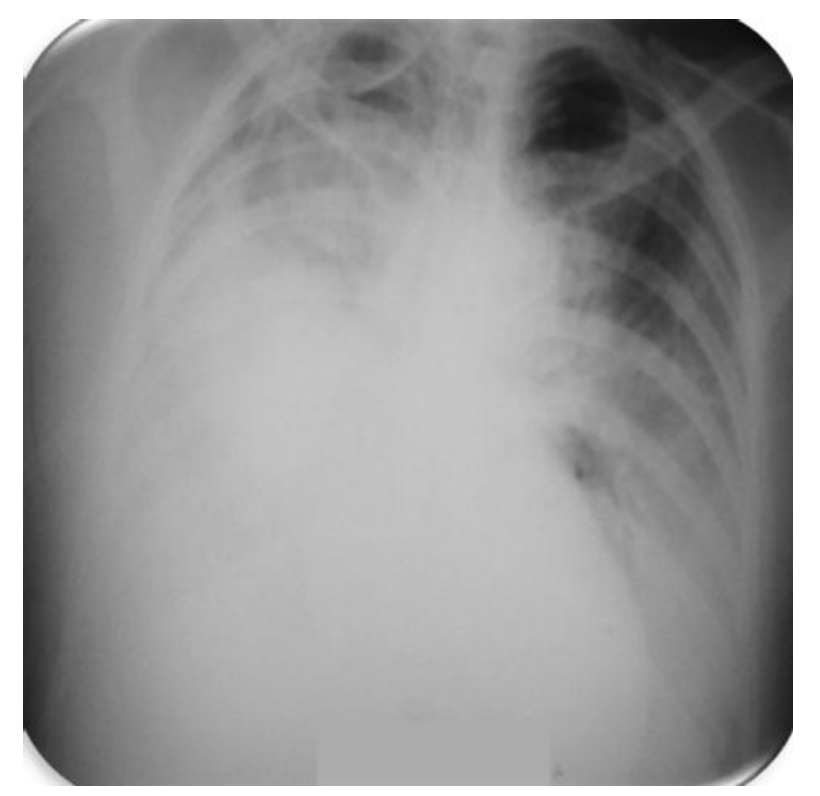

Рис. 4

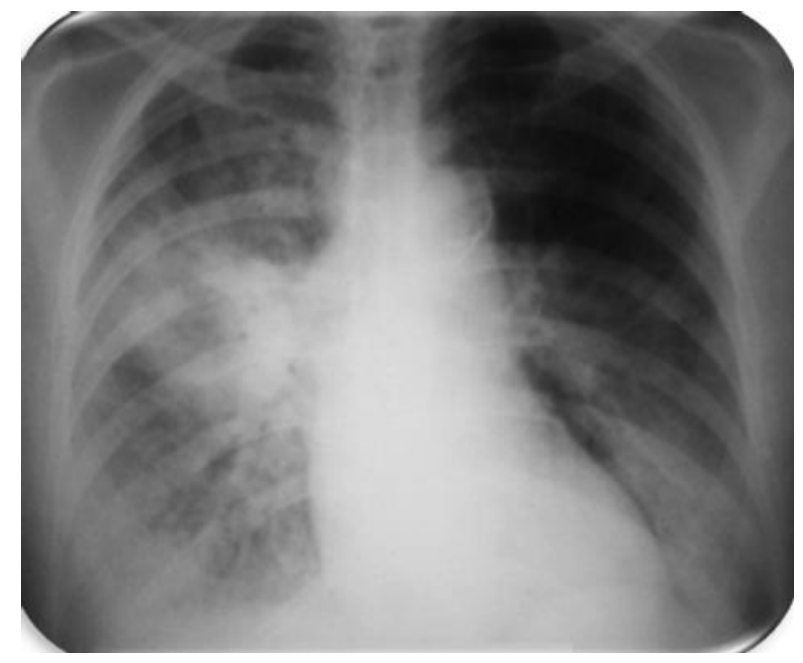

Рис. 5

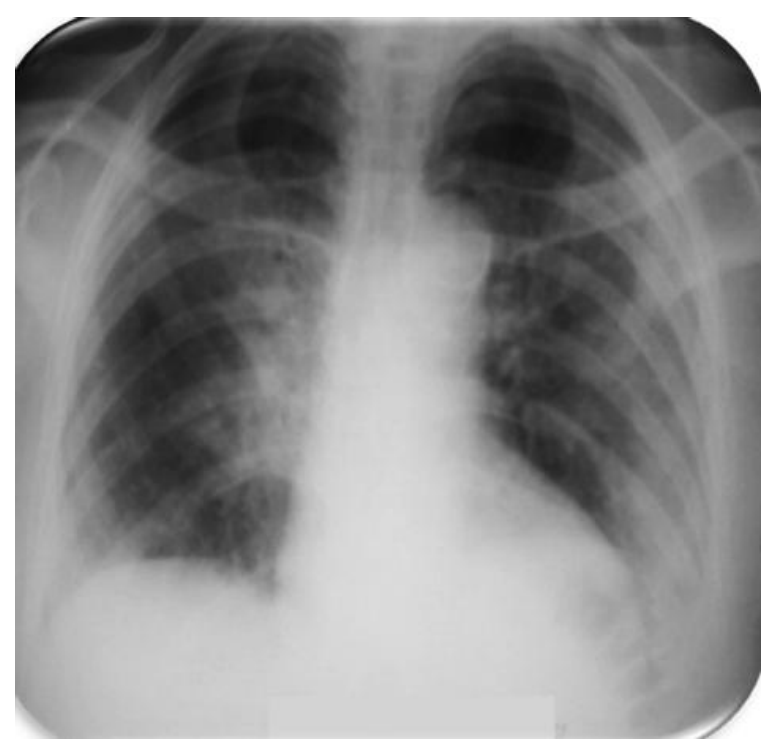

Рис. 6

- 0,4; з 6-ї доби переведена на спонтанне дихання із масковою кисневою терапією та потоком кисню 6-4 л/хв. Поступово стан із покращенням клінічно та рентгенологічно (рис. 7).

Динаміка лейкоцитозу: 15,6 (I-ша доба) - 12,9 (6-та доба) - 7,4 (14-та доба); динаміка сечовини 26,3 - 12 - 6,4 ммоль/л відповідно, креатиніну 0,08 - 0,1 - 0,07 ммоль/л, тромбоцитів 248 тис. - 157 тис. - 256 тис. Показники гематокриту за час лікування в межах 0,36-0,4 л/л. АКТ ОГК на 9-ту добу перебування у ВАІТ - двобічна полісегментарна пневмонія із дрібними фокусами інфільтрації та розпаду. В зв'язку ізперсистуючоютемпературною реакцією проведено заміну антибактеріальної терапії на 10-й день: тиментин - 3200 мг 4 рази на добу, амікацин 1,5 г на добу, флуконазол - 200 мг на добу. Температура тіла та показники крові стійко нормалізовані на 15-ту добу, для подальшого лікування хвору переведену в соматичне відділення (рис. 8). 


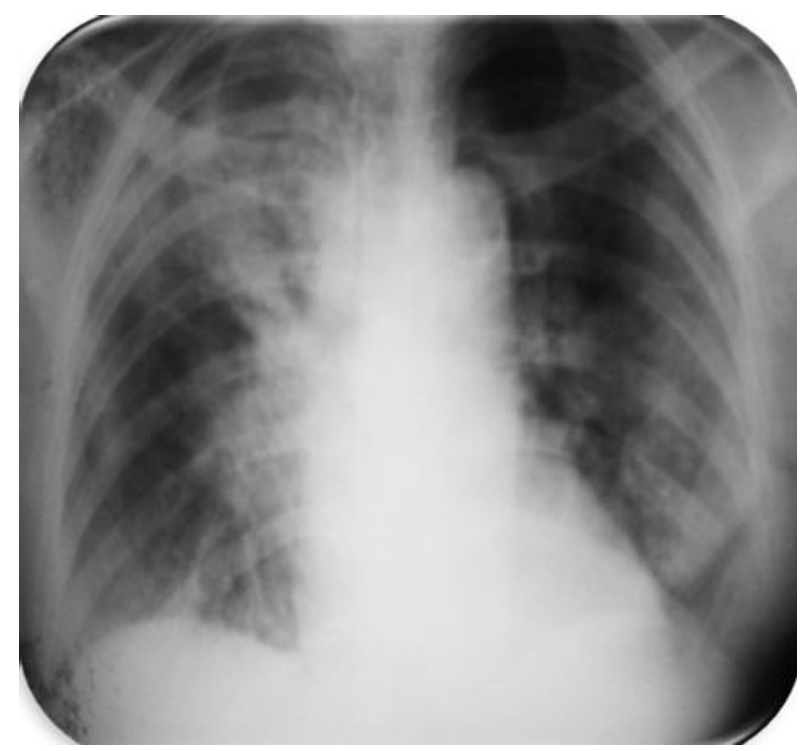

Рис. 7

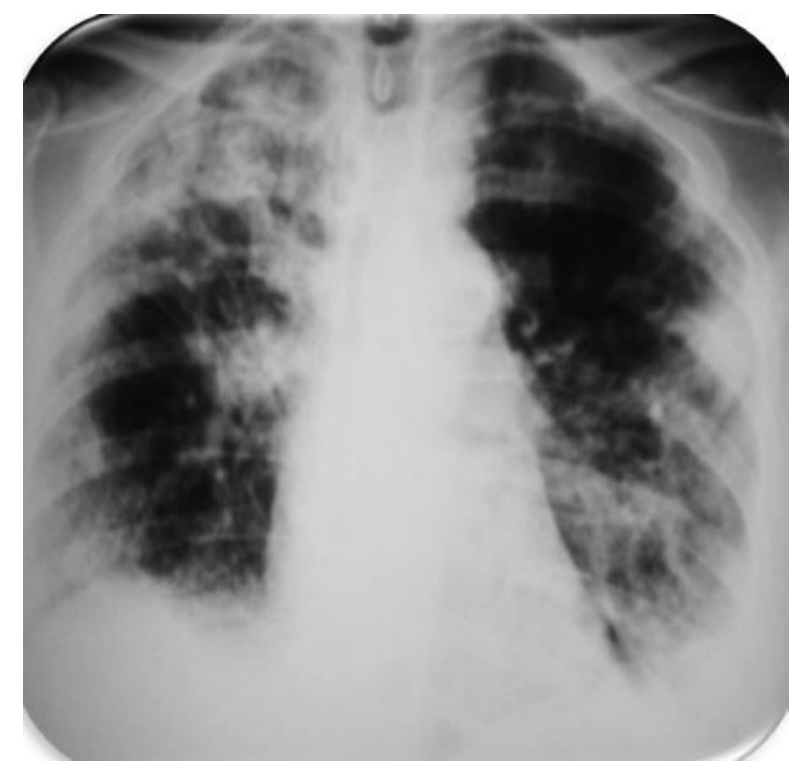

Рис. 8

Клінічний випадок 2. Хвора К., 1981 р. н., перебувала на стаціонарному лікуванні в пульмонологічному відділенні ХОЛ з 17.03.11 до 21.03.11 року з діагнозом негоспітальної двобічної нижньочасткової полісегментарної пневмонії, ДН 1 ст, вагітність друга, 26 тижнів. При госпіталізації скарги на невиражену задишку в спокої, малопродуктивний кашель із виділенням слизово-гнійного харкотиння, гіпертермію до субфебрильних показників. 3 анамнезу: хворіє 4-й день, захворювання пов’язує 3 перенесеним ГРВІ. Вагітність друга, перебіг без особливостей, перша закінчилась фізіологічними пологами. При рентгенологічному обстеженні: інфільтративні зміни двобічно в нижній частці. 3 амбулаторної карти: консультована інфекціоністом у день госпіталізації: двобічна, не виключено постгрипозна, полісегментарна пневмонія (рис. 9).

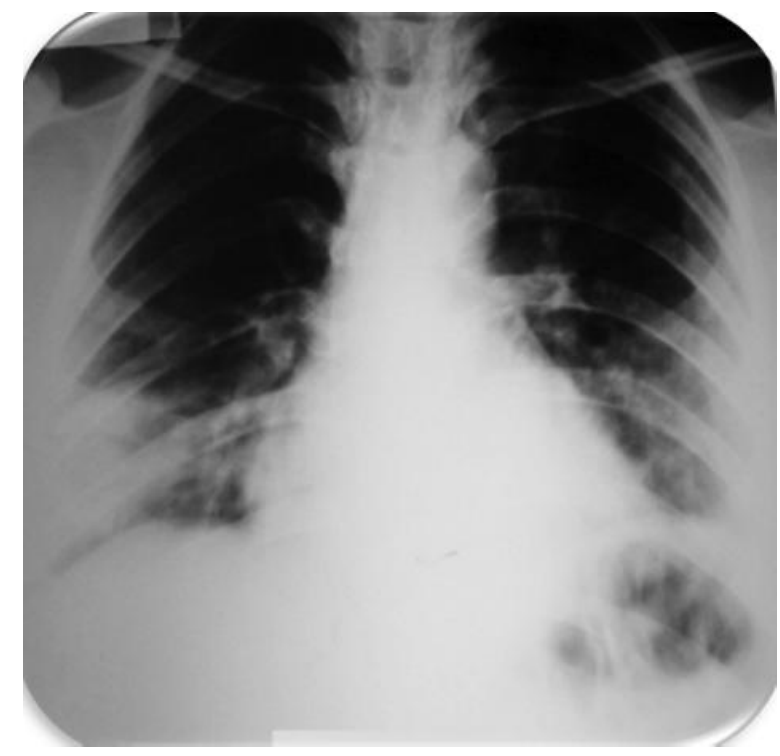

Рис. 9

Отримувала лікування відповідно до акушерського протоколу: аугментин - 1.03 рази на день, роваміцин 3 млн (1 таб.) 3 рази на день, реосорбілакт - 200 мл, сироп “Гербіон”. За час лікування стан хворої не покращився, з вечора 20.03.11 відмічає прогресування задишки, явищ інтоксикації. У зв'язку із прогресивним зниженням сатурації кисню $\left(\mathrm{SpO}_{2}-74\right.$ \%), хвору для подальшого лікування терміново переведено у ВАІТ.

21.03.2011 р. хвору прийнято у ВАІТ зі скаргами на задишку, кашель 3 виділенням харкотиння слизово-гнійного характеру. При госпіталізації клінічний стан хворої тяжкий. У свідомості, адекватна, доступна мовному контакту. Гемодинаміка стабільна, АТ - 110/70 мм рт. ст. Пульс - 110/хв задовільних властивостей, ритмічний. Дихання самостійне, ЧД - 28-30/хв. Хворій через маску подається зволожений $\mathrm{O}_{2}$. $\mathrm{SpO}_{2}-83-85 \%$ при $\mathrm{FiO}_{2}-40$ \%. Над легенями дихання жорстке, велика кількість вологих та сухих хрипів, ослаблене в нижніх відділах з обох сторін. Живіт м’який при пальпації, неболючий, збільшений відповідно до терміну вагітності. Рухи плода відчуває. Обстежена: рентгенографія ОГК: від 21.03.11 негативна динаміка, наростають інфільтративні зміни в обох легенях (рис. 10).

Проведено заміну антибіотиків: меронем - 1,0 3 рази на день, азитроміцин - 500 мг 2 рази на день. Незважаючи на терапію, яку проводили, у хворої відзначено подальше зниження сатурації до 6870 \%, прогресування ознак ДН, у зв’язку з чим пацієнтку переведено на неінвазивну ШВЛ у режимі BIPAP апаратом “Ivent” 22.03.11. Рентгенологічно (рис. 11).

24.03.11 у зв’язку з наростанням ДН та неефективністю неінвазивної ШВЛ хвору інтубовано і переведено на інвазивну ШВЛ апаратом “Newport” у режимі SIMV з параметрами: ДО - 550 мл, ЧД - 


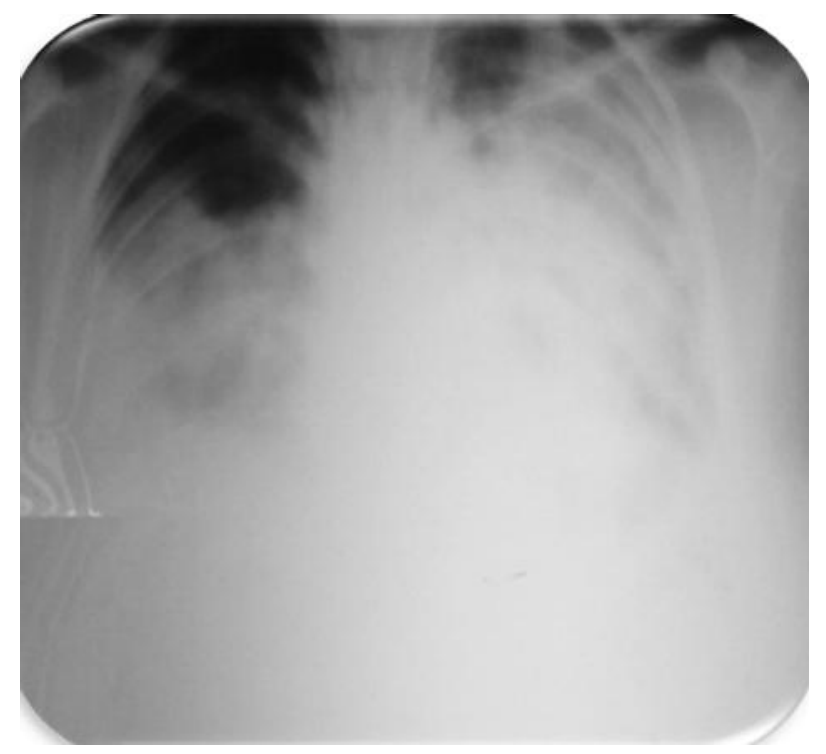

Рис. 10

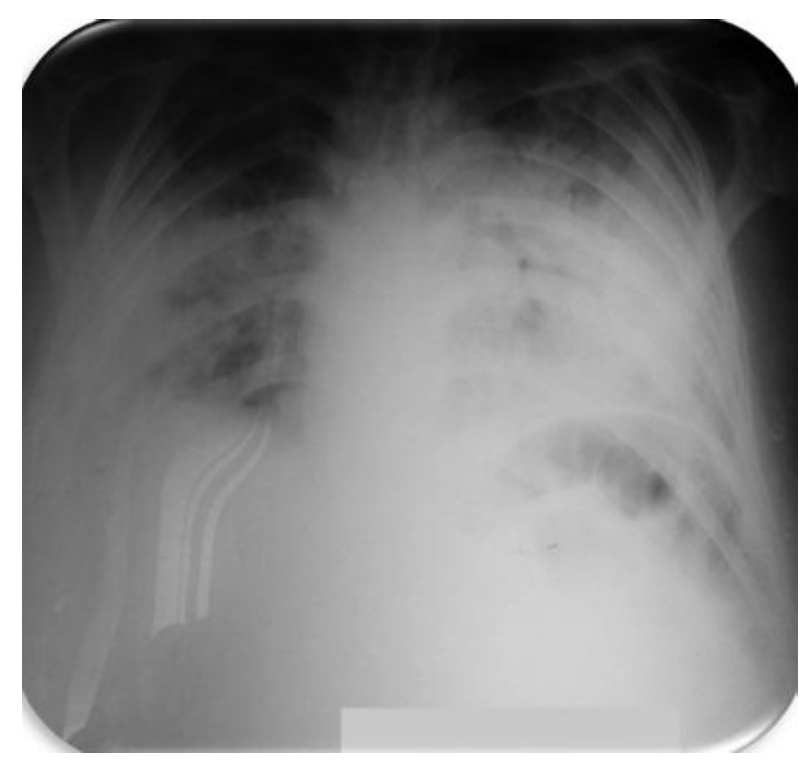

Рис. 11

16/хв, Тi:Te - 1:2, $\mathrm{FiO}_{2}-0,6$, ПТКВ - 8 см вод. ст. Клінічний стан хворої залишається вкрай тяжким, хвору седовано, на апаратному диханні. $\mathrm{SpO}_{2}-$ 82-85 \%. До лікування додано зивокс - 600 мг 2 рази на день, до лікування додано дексазон 4 мг 2 рази на добу, амікацин - 0,5 2 рази на добу, переглянуто доцільність застосування зивоксу, враховуючи його нефротоксичність, амікацин 0,5 + 30 мл фізіологічного розчину по 1 мл щогодини ендотрахеально, Per os - до 2,5 л харчування через зонд. Рентгенологічно (рис. 12).

28.03.11 за життєвими показаннями хворій було здійснено трахеостомію. Дихання ШВЛ через ТСТ, регулярно проводилась санація ТБД бронхоскопістом. Змінено параметри ШВЛ - ПТКВ до 12 см. Рентгенологічно, на фоні ПТКВ 12 см $\mathrm{H}_{2} \mathrm{O}$. Клінічну картину розцінено як тяжкий РДС (рис. 13).

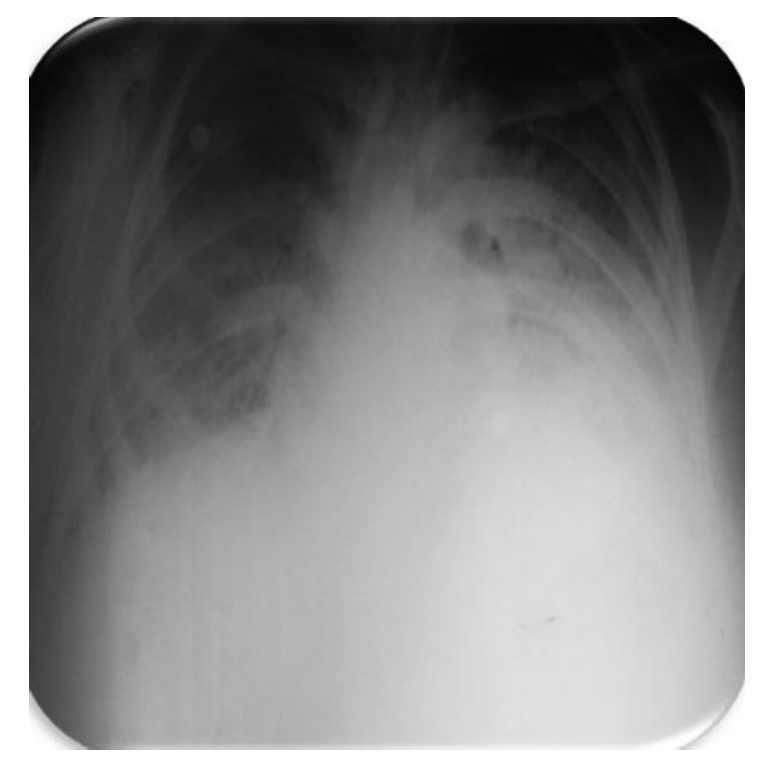

Рис. 12

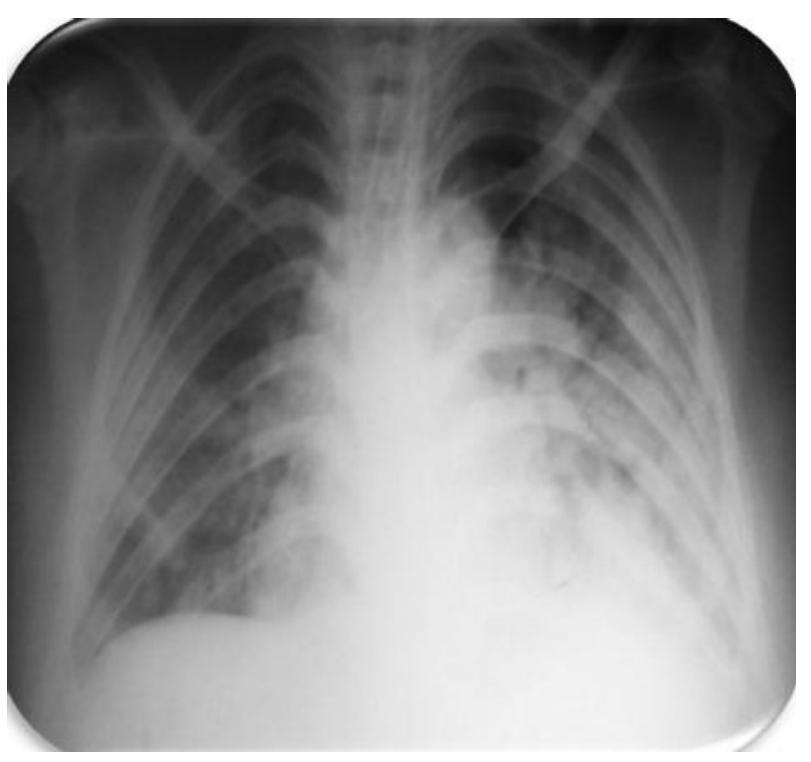

Рис. 13

При проведенні бронхоскопій (щоденно) з ТБД виділяються геморагічні зліпки бронхів. Відзначено кровоточивість трахеостомічної рани, контактну кровотечу при БФС. Хворій проведено трансфузії каріоплазми - 10 мл/кг тричі, відмінено клексан 0,2, призначено мембраностабілізатори - дицинон. Рентгенологічно (рис. 14).

31.03.11 проконсультовано професором кафедри акушерства та гінекології з курсом анестезіології Київської академії післядипломної освіти Р. О. Ткаченком Рекомендовано: рестриктивний режим інфузійної терапіі не більше 500 мл/добу; розширити об'єм ентерального харчування та введення рідини; продовжити протигрибкову терапію; замінити меронем на коломіцин; зменшити ГКС до 4 мг на добу; відмінити таміфлю; аскорбінова кислота до 10 мл двічі на добу; відмінити 


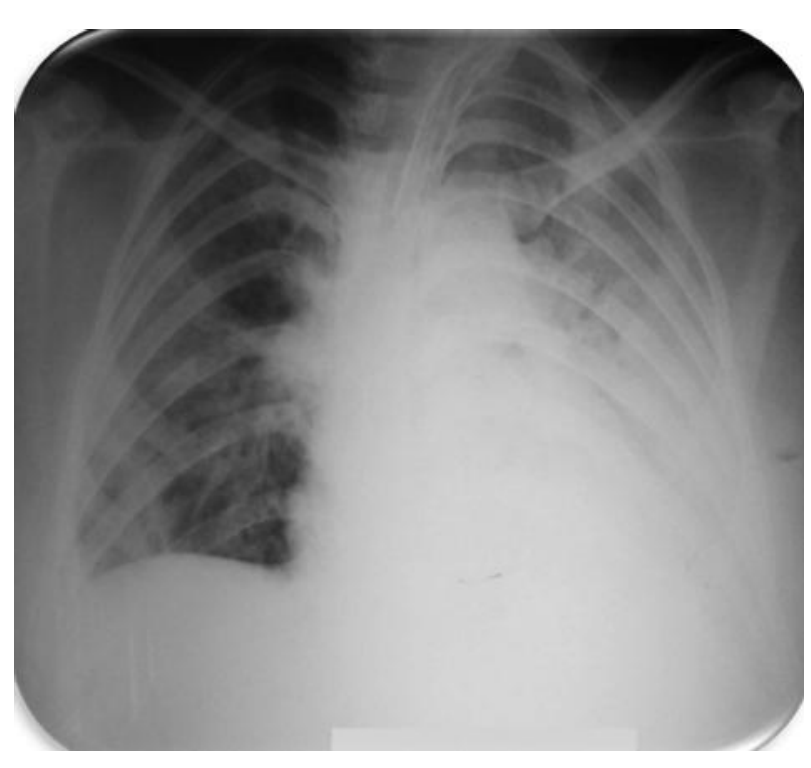

Рис. 14

каріоплазму та продовжити клексан - 0,2 мл/ добу. Рентгенологічно (рис. 15).

При проведенні ШВЛ регулярно здійснювали повороти хворої на живіт та ШВЛ в такій позиції до 2-х год на добу. $\mathrm{FiO}_{2}-0,8, \mathrm{SpO}_{2}-88 \%$. Рухи плода відчуває, щоденно оглянута акушеромгінекологом, за даними УЗД - плід живий. Неодноразово були проведені консультації в телефонному режимі з проф. Ф. С. Глумчером. Рекомендовано розглянути можливість родорозрішення (враховуючи термін вагітності, у хворої різко порушене діафрагмальне дихання). Рентгенологічно (рис. 16).

11.04.11 о 10:00 в хворої настала зупинка серцевої діяльності, розпочато реанімаційні заходи, о 10:20 на моніторі зафіксовано фібриляцію шлуночків, проведено дефібриляцію о 10:42, відбулося відновлення самостійної серцевої діяльності. Сві-

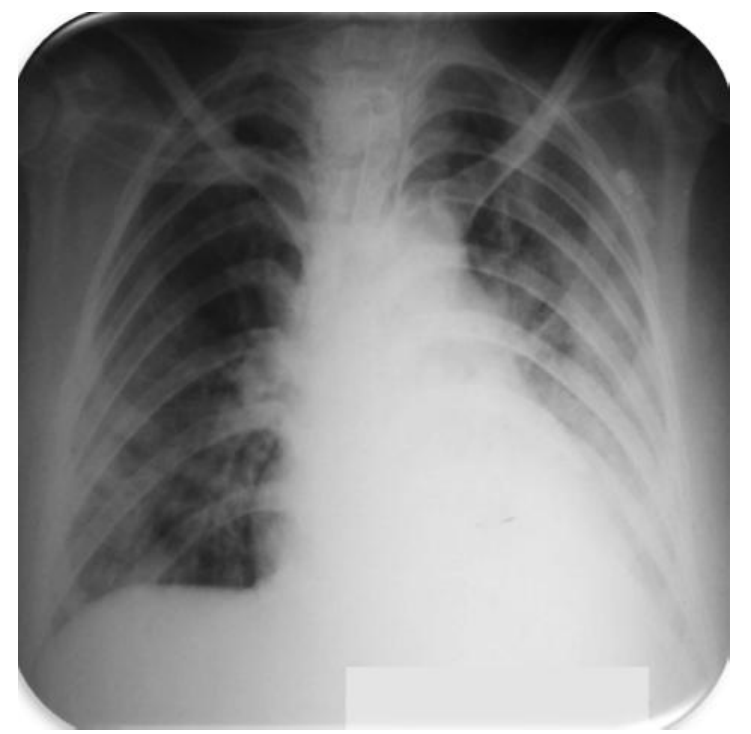

Рис. 15

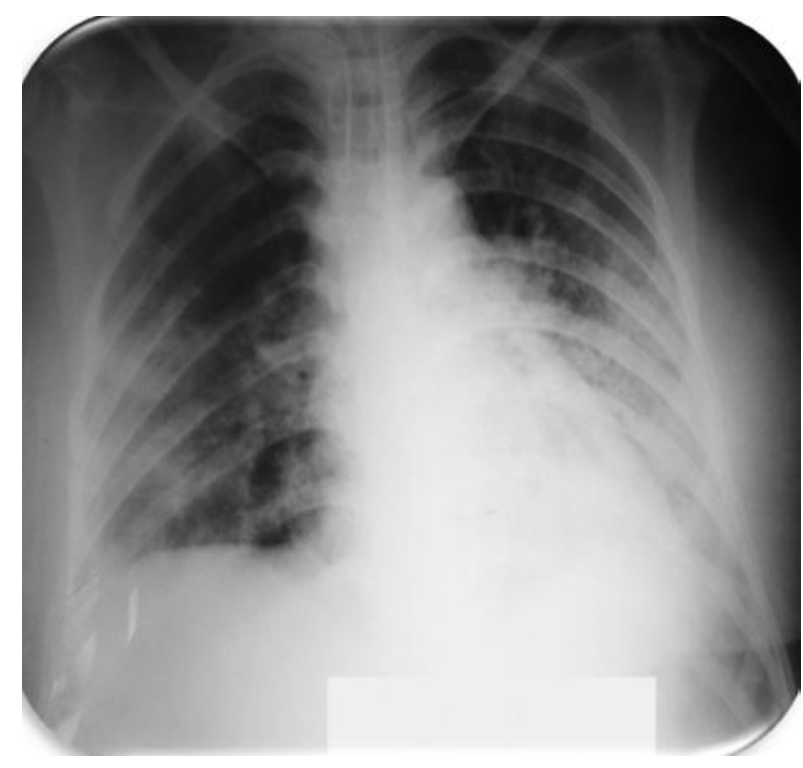

Рис. 16

домість у пацієнтки відновилась ввечері, плід живий, серцебиття /+/. Рентгенологічно (рис. 17).

Консиліум лікарів розглянув можливість родорозрішення за умови зрілості плода. За даними УЗД, пліддопологівнеготовий.Станхвороївкрайтяжкий, продовжується ШВЛ, інфузія симпатоміметиків. 13.04.11 о 5:50 у хворої раптово знижується $\mathrm{SpO}_{2}$ до 45 \%, проведено санацію ТБД-виділяються гнійногеморагічні зліпки бронхів, раптово настала зупинка серця, негайно розпочато реанімаційні заходи, о 5:53 серцева діяльність відновилась, налагоджено інфузію симпатоміметиків, продовжувається ШВЛ з $\mathrm{FiO}_{2}-$ $80 \%$ і $\mathrm{SpO}_{2}-92 \%$. Опритомніла відразу, ізотропну підтримку припинено. Плід живий. Продовжено респіраторну терапію РДС. УЗД: положення плода повздовжнє, серцебиття плода ритмічне - 170/хв. Рентгенологічно (рис. 18).

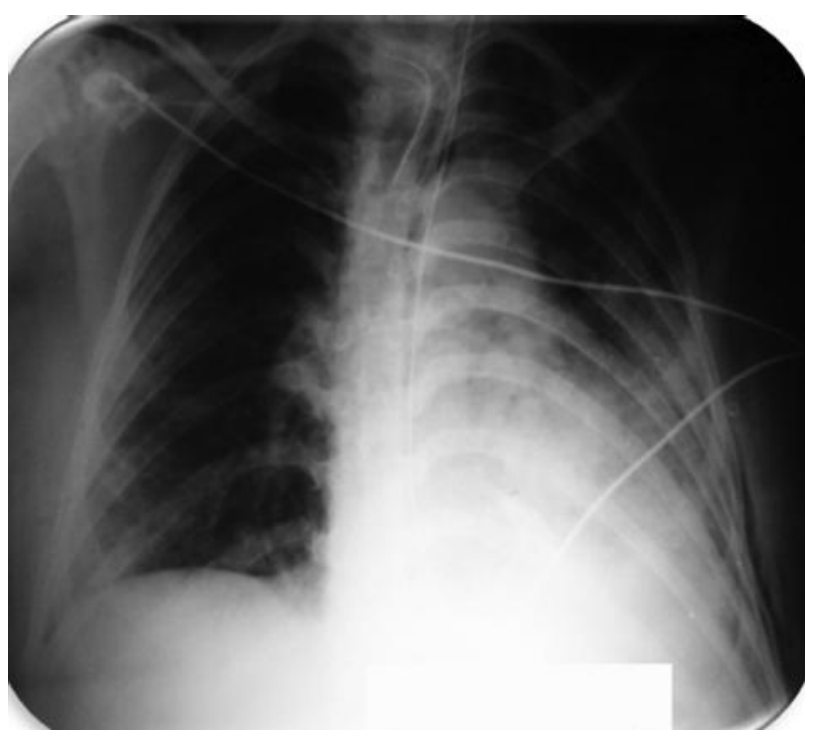

Рис. 17 


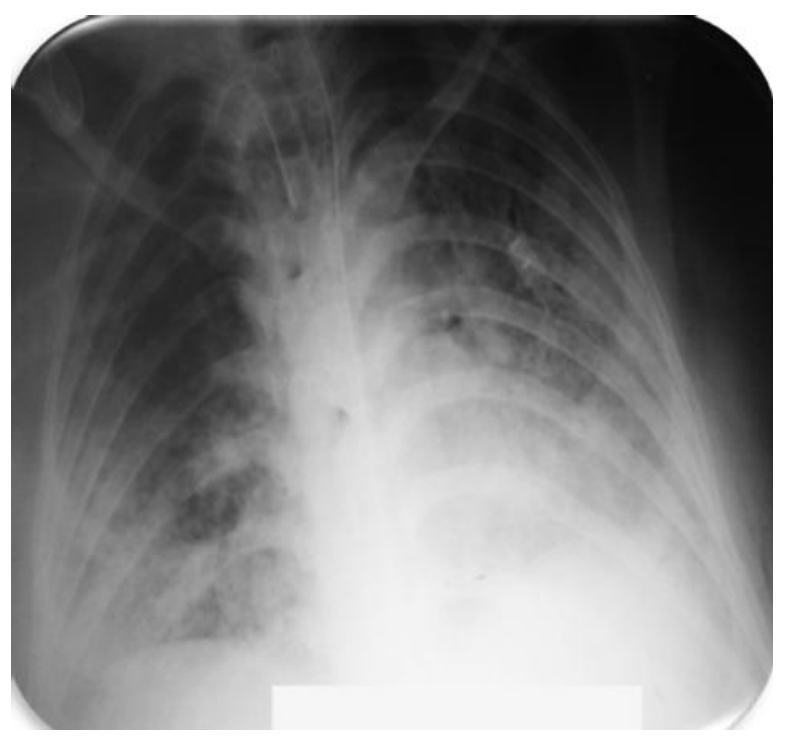

Рис. 18

19.04.11 проведено консультацію телефоном з головним акушером-гінекологом МОЗ України В. В. Камінським - рекомендовано родорозрішення не проводити. У хворої систематично санується велика кількість слизово-геморагічного харкотиння підвищеної щільності. Після санації ТБД періодично хвора переходить на самостійне дихання, швидко виснажується. Рентгенологічно (рис. 19).

25.04.11 скарги на зниження рухової активності плода. Серцебиття плода стетоскопом та кардіомонітором не визначається. УЗД плода: серцебиття плода не визначається. Висновок: антенатальна загибель плода в терміні 31 тиждень. Рекомендовано: переривання вагітності за медичними показаннями шляхом амніоцентезу (гіпертонічним розчином) через передню черевну стінку. Пологи через природні пологові шляхи із динамічним спостереженням реаніматолога. 25.04.11 о 22:00 проведено трансабдомінальний амніоцентез.

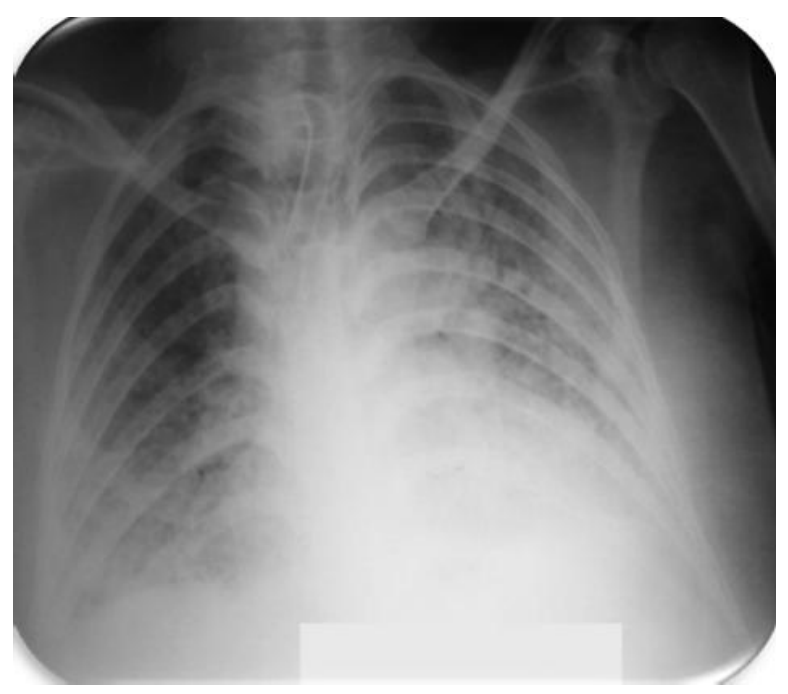

Рис. 19
26.04.11 о 20:40 відбулися передчасні пологи мертвим, мацерованим плодом. О 20:50 відділився послід із зеленими оболонками. Плід та послід документовано, переданонаПГД. О21:00 проведено інструментальну ревізію стінок порожнини матки. 27.04.11 дихання самостійне адекватне через ТСТ. ЧД - 24-25/хв, подається зволожений кисень, $\mathrm{SpO}_{2}$ 95-96 \%, $\mathrm{FiO}_{2}-0,4$. Рентгенологічно (рис. 20).

29.04.11 загальний стан тяжкий із позитивною динамікою. 4.05.11 стан із покращенням, стабільний. Рентгенографія ОГК: позитивна динаміка. Зменшились зливні інфільтративні зміни. Зберігається периваскулярна інфільтрація в середніх і нижніх легеневих полях (рис. 21, 22).

Таким чином, родорозрішення миттєво покращило загальний стан пацієнтки, дихання самостійне через ТСТ, кашель продуктивний. Продовжено реабілітаційні заходи.

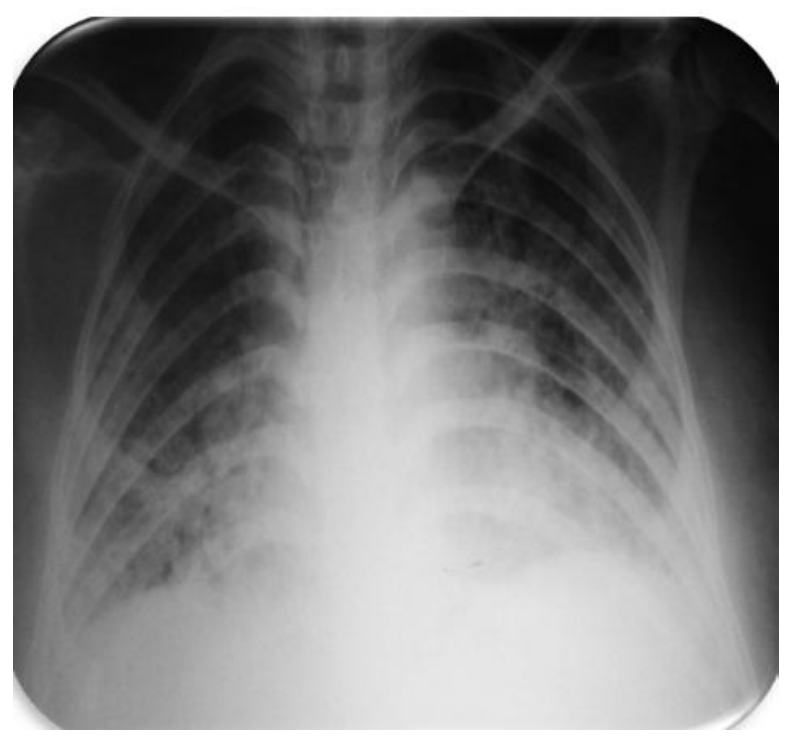

Рис. 20

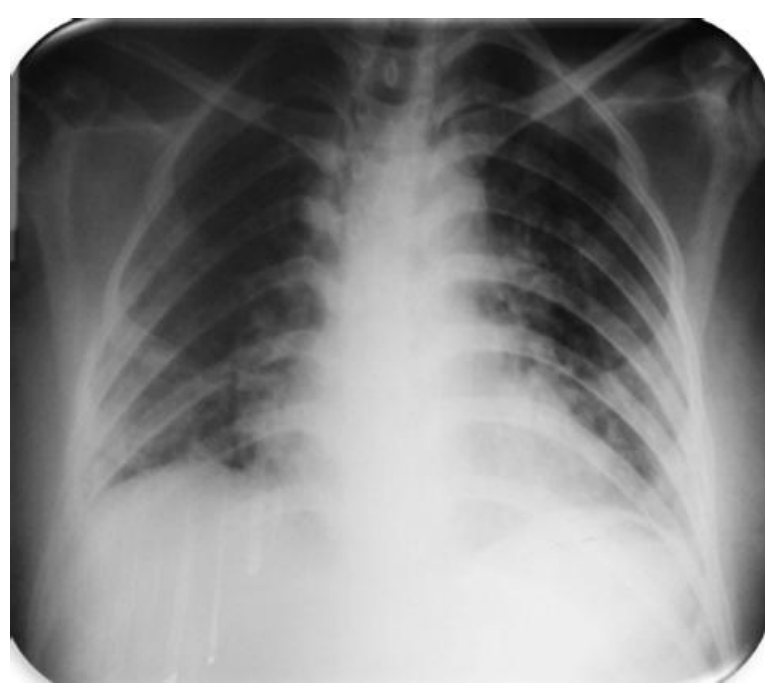

Рис. 21 


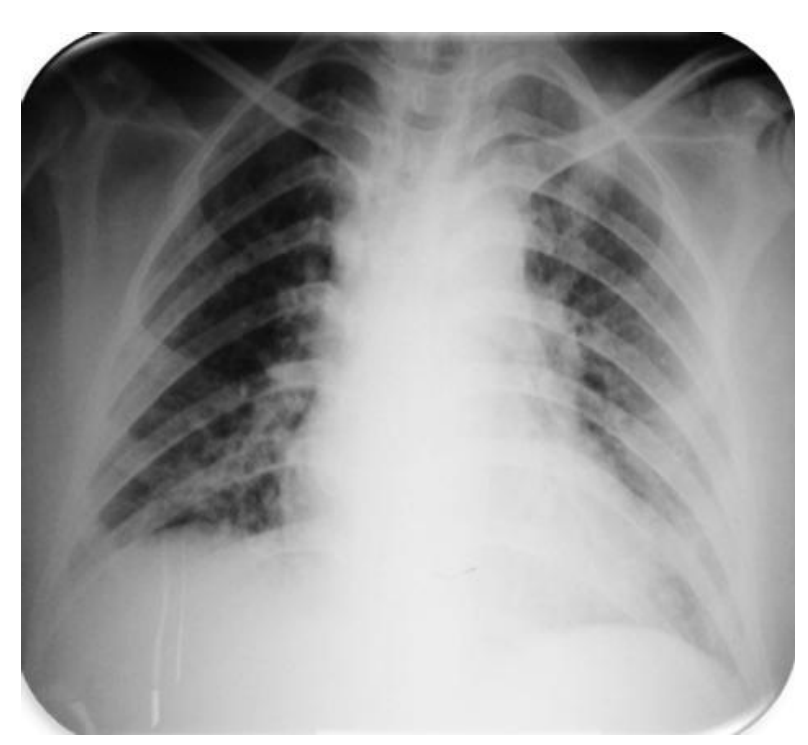

Рис. 22

Отримувала терапію в об'ємі: в різних дозуваннях інфузійну терапію, лазолван, еуфілін, ношпу, омепразол, реосорбілакт, дексазон, клексан, сибазон, тіопентал, дипрофол, таміфлю, амікацин, фуросемід, анальгін, димедрол, маніт, ацелізин, кріоплазму, віфенд, квамател, каліпоз, фрезубін, строфантин, сорбіфер, глобірон, папаверин, магнезію, лінекс, йогурт, веноімун, кордарон, допамін, адреналін, гідрокортизон, дексазон, атропін, цераксон, АЦЦ, урсосан, глутаргін, діаліпон, церукал, ессенціале, осетрон, актовегін, берлітіон, орофер, еритропоетин, відмиті еритроцити, пред-

\section{СПИСОК ЛІТЕРАТУРИ}

1. Наказ МОЗ України № 128 від 19.03.2007 р. “Про затвердження клінічних протоколів надання медичної допомоги за спеціальністю “Пульмонологія”. - С. 24-130.

2. Наказ МО3 №189-адм від 20.05.2009 “Про затвердження Протоколу діагностики та лікування нового грипу А (H1N1) - (Каліфорнія) для дорослих”.

3. Внебольничная пневмония у взрослых: практические рекомендации по диагностике, лечению и профилактике. 3-е изд. : пособие для врачей / [А. Г. Чучалин, А. И. Синопальников, Р. С. Козлов и др.]. - М., 2010.

4. Management of acute respiratory failure with noninvasive ventilation in the emergency department Fernando Ayusto Baptista et al., Córdoba. Secretaría Científica y de Calidad de SEMES-Andalucía. Spain. 2EPES 061 Córdoba. Spain. 3Medicina Familiar y Comunitaria. Servicio de Cuidados Críticos y Urgencias. Hospital Valle de los Pedroches. Pozoblanco, Córdoba. нізолон, окситоцин, фуцис. Протибактеріальну терапію отримувала відповідно до антибіотикограми: з 21.03.11 до 23.03.11 меронем, азитроміцин; 3 24.03.11 до 1.04.11 меронем, лінезолід, амікацин в ETT; з 1.04.11 до 9.04.11 зивокс, коломіцин, амікацин в ЕTT; з 9.04. до 15.04.11 моксиф, амікацин в ETT; з 15.04.11 до 30.04.11 сульперазон, роваміцин, амікацин в ЕТT; з 30.04.11 до 5.05.11 сульперазон, амікацин в ЕТТ; з 5.05.11 антибіотики відмінено. Родорозрішення сприяло швидкому відновленню самостійного ефективного дихання. Відзначаємо такі моменти: ШВЛ - 35 днів з наступним одужанням; тяжка (постгрипозна?) пневмонія (враховуючи анамнез, швидке прогресування рентгенологічних змін в легенях, геморагічні прояви) із позитивним наслідком; вентиляція в положенні пацієнта на животі при лікуванні РДС; ефективність комбінації лінезолід + коломіцин + вориконазол.

Висновки. 1. Перебіг пневмоній у пацієнтів із супутніми імунодефіцитними станами відрізняється затяжним перебігом та швидким розвитком тяжкої дихальної недостатності.

2. Сучасні респіраторні стратегії (неінвазивна вентиляція легень, протективна вентиляція із використанням малих об'ємів) є ефективними методиками інтенсивної терапії.

3. Важливим є урахування локального мікробного пейзажу виділень (широке розповсюдження мікроорганізмів групи ESCAPE).

Spain. - Secretaría de Urgencias de SEMERGEN. Spain. - Emergencias. - 2009. - № 21. - P.189-202.

5. Noninvasive Ventilation for Acute Respiratory Failure Dean R Hess PhD RRT FAARC. - Respir Care. - 2013. - № 58 (6). P. 950-969.

6. BTS Guideline. Non-invasive ventilation in acute respiratory failure British Thoracic Society Standards of Care Committee. Thorax. - 2002. - № 57. - P. 192-211.

7. Колосов В. П. Внебольничная пневмония (клиническое течение, прогнозирование исходов) / В. П. Колосов, Е. Ю. Кочегарова, С. В. Нарышкина. - Благовещенск, 2012. - 124 с. 8. Мэскэл Н. Руководство по респираторной медицине / Н. Мэскэл, Э. Миллар ; пер. с англ. под ред. С. Н. Авдеева. М. : ГЭОТАР - Медиа, 2014. - 600 с.

9. Пол Л. Марино. Интенсивная терапия / Пол Л. Марино ; пер. с англ. под общей редакцией А. П. Зильбера. - М. : ГЭОТАР - Медиа, 2010. - 768 с.

Отримано 01.07.15 